\title{
Variations in wood tratis in micro and macro propagated plantation woods of Populus deltoides Bartr. ex Marsh
}

\author{
Pramod K. Pande ${ }^{1}$, Ramesh C. Dhiman ${ }^{2}$ \\ ${ }^{1}$ Wood Anatomy Discipline, Botany Division Forest Research Institute, Dehradun, India; \\ ${ }^{2}$ WIMCO Ltd. (Wimco Seedlings Division) Bagwala, Udhamsing Nagar, India. \\ Email: pandep123@rediffmail.com
}

Received 13 July 2010; revised 18 July 2010; accepted 21 July 2010.

\begin{abstract}
The paper presents a comparison between intra-ramet, intra-clonal and inter-clonal variations in girth at breast height (gbh), fiber length, fiber diameter, wall thickness, vessel element length, vessel element diameter and specific gravity in the ramets of L34, G3 and S7C15 clones of Populus deltoides at the age of 6 years old produced from planting material grown by macro- and micro-propagation techniques. Variance ratio $(F)$ test indicated that intra-ramet variations were non-significant for all the characters except specific gravity for height in L34 for macro and specific gravity and vessel element diameter for radial locations for micro, and fiber length for G3 (micro) for height, and specific gravity for radial location and fiber length for height for S7C15 clone for both the techniques. The clone L34 showed the significantly higher girth followed by G3 and S7C15. The variations were significant for girth, vessel element length and specific gravity between the wood produced from planting stocks grown by two techniques. Intra-clonal variations were significant for fiber length, fiber diameter and vessel element length. In general wood element's dimensions and specific gravity increased from bottom to top and pith to periphery radial locations. G3 clone was different from the L34 and S7C15 clone for the wood traits. The three different clones of Populus deltoides showed variability in wood anatomical properties and specific gravity in the woods grown from macro- and micro-propagated planting stock. So, the plantation raised by two techniques could not produce similar type of wood even from the same clone. G3 clone was the exception as it did not show variation in wood traits for two techniques. Intra-clonal variations in all the three clones of $P$. deltoides indicated that wood traits were not stable within the population of same clone grown by either method.
\end{abstract}

Keywords: Axial Variation; Radial Variation; Vessel Element's Dimension; Fiber Dimensions; Specific Gravity

\section{INTRODUCTION}

Populus deltoides is extensively used in plywood, match sticks, sports goods, wood-composites and paper industry. It is grown under different forestry programs as clonal plantations to ensure the genetic superiority for better growth and superior wood quality. Poplar is routinely propagated through shoot cuttings (macro-propagation). But, some plantations were also raised through micro-propagation techniques (tissue culture).

The variability in wood anatomical characteristics has profound influence on the properties of wood $[1,2]$. Features of interest in this connection include cell size, proportion and arrangements of different elements and specific gravity. The general pattern of variation in wood element dimensions is found not only within a species but also observed within a tree [3-6].

Variations in the dimensions of wood elements and specific gravity both within the ramet and among the clones have come under close scrutiny in recent years. There are reports available on the variation in wood anatomical and other properties in different clones of Populus elsewhere [7-10]. It showed that existing literature is only available on the screening of wood quality of poplar clones propagated by macro-propagation technique. No report is available on the comparison of variations on wood properties of macro-propagated with micro-propagated plantation wood.

The growth and wood quality are the two important parameters for the assessment of clones considering their end uses. The parameters viz., wood elements dimensions, specific gravity and growth should be compared for two types of plantation woods viz. macro and micro-propagated, so that superior mass propagation technique can be recommended for commercial plantations for its specific end uses. 
The present paper deals with the intra-ramet, intraclonal and inter-clonal variations in wood anatomical parameters and specific gravity in plantation wood of three clones of $P$. deltoides viz., L34, G3. S7C15 which were produced from the planting stock grown by the macro- and micro-propagation techniques. This efforts was made to compare the wood properties of the wood produced thereof and harvested at 6 years age.

\section{MATERIALS AND METHOD}

\subsection{The Experimental Site}

Study site was located at Rudrapur (Udhamsing Nagar), Uttarakhand, India. It is situated at around $28^{\circ} \mathrm{N}$ latitude; $78^{\circ} \mathrm{E}$ longitude and at the altitude of $200 \mathrm{~m}$ asl. The annual rainfall was $1200 \mathrm{~mm}$; of which $88 \%$ occurs during June-August. The average maximum summer temperature (April-June) was $36.7^{\circ} \mathrm{C}$ and average minimum temperature (December-February) was $7.5^{\circ} \mathrm{C}$ (2005-06). The soil of the site was sandy loam.

\subsection{Planting Material}

The micro-propagated plantlets of L34 and G3 clones maintained in containers (root trainers) were procured from Tata Energy Research Institute, New Delhi (India) during February/March 1996, whereas, that of S7C15 clone were procured from the State Forest Department (Haldwani) which they also reportedly procured from the Tata Energy Research Institute, New Delhi (India) during the same period. The plantlets of these three clones were planted along with the standard shoot cuttings (20-22 cm long with 3-4 alive and sound buds) in the nursery beds at the spacing of $80 \mathrm{~cm}$ x $50 \mathrm{~cm}$ at Research and Development Complex of Wimco Seedlings Ltd., Bagwala (India) during the month of March 1996. The nursery plants were grown through out the year by adopting standard cultural operations followed in growing poplar nurseries. Entire Transplants (ETPs-common name for the planting stock of poplar) of three clones were grown by using micro- and macro-propagation techniques.

The field trial for comparing the performance of the planting stock originally produced by both the techniques was established in Plot No. 6 of Nurpur Block of Parag Agro Farm Ltd. Kichha, Udham Singh Nagar, Uttrakhand in the Randomised Block Design having four replications. Each replicated plot was having 25 plants planted at $7 \mathrm{~m} \times 3 \mathrm{~m}$ spacing over an area of $25 \mathrm{~m}^{2}$. The total experimental area was therefore $12600 \mathrm{~m}^{2}$ (1.26 ha) having planting stock of three clones grown from microand macro-propagated techniques (six treatments) in four replications. The trial was planted in the field on $18^{\text {th }}$ January, 1997. The data on the growth and development of these trees was recorded each year; however the data during the harvesting of the trees at six years is only presented in this paper to indicate the growth variation in the trees during felling. The final survival of the entire trial was $65.7 \%$ in which planting stock of micropropagated origin gave slightly better survival in all the three clones when compared with that of macro-propagated planting stock. The average tree in term of diameter growth was located in each replicated plot and trees from only three replicates were considered for the study. Height and diameter growth of each average tree from each clone in both macro- and micro-propagated categories considered for the present study are given in Table 1.

\subsection{Sampling}

Three ramets, propagated each from micro- and macropropagated technique for each clone, were consider for this study. In total 18 ramets were felled during January, 2003 for the study. The height and girth of each tree was recorded. Four transverse discs of $10 \mathrm{~cm}$ thickness were cut form the trunk; one each at the base and from different three vertical heights at the $2.5 \mathrm{~m}$ regular intervals. In total, 72 discs were collected. The discs were referred as D1, D2, D3 and D4 from the base. Each disc was divided into three peripheral direction i. e. north, north-east and south-west to cover the peripheral variations. Each direction was divided into three pith to periphery radial locations viz. inner, middle and outer. Besides, a central block (pith) from each disc was also considered to see the variation in pith wood. In total 720 sample blocks were considered for anatomical studies like fiber length, fiber diameter, wall thickness, vessel element length, vessel element diameter and specific gravity. Standard laboratory methods were followed for the preparation of macerations. Wooden chips were fragmented into small pieces and put in the test tube. The material was macerated under $50 \% \mathrm{HNO}_{3}$ and a pinch of $\mathrm{KClO}_{3}$. The macerated wood elements were thoroughly mixed and were spread on a glass slide and observations were taken under compound microscope [11]. Measurements for fiber length, fiber diameter, wall thickness, and vessel element length and vessel element diameter were taken from the macerated wood. Twenty five unbroken cells were

Table 1. Growth data of selected clones.

\begin{tabular}{|c|c|c|c|c|c|}
\hline \multirow{2}{*}{ Clone } & \multirow{2}{*}{ Origin } & \multicolumn{2}{|c|}{ Average Height (m) } & \multicolumn{2}{|c|}{ Av Diameter (cm) } \\
\hline & & Macro & Micro & Macro & Micro \\
\hline L. 34 & Lalkuan & $28.3 \pm 0.37$ & $20.1 \pm 0.42$ & $27.9 \pm 0.49$ & $18.4 \pm 0.85$ \\
\hline S7C15 & USA & $23.3 \pm 0.32$ & $19.5 \pm 0.64$ & $22 \pm 0.21$ & $18 \pm 0.19$ \\
\hline G3 & USA & $25.1 \pm 0.07$ & $15.3 \pm 0$ & $22.9 \pm 0.32$ & $12.1 \pm 0$ \\
\hline
\end{tabular}


sampled for the measurement of each parameter [12]. Specific gravity was determined by using the following formula [11].

Basic density $=$ Oven dry weight/green volume

The basic density was converted into specific gravity as density of a wood sample relative to the density of water.

\subsection{Statistical Analysis}

The data obtained were statistically analyzed (using SPSS 10) Multivariate analysis to test the intra-ramet, intra-, inter-clonal variations and variations between the wood produced from planting stock originated by two techniques $i$. e. macro and micro- propagation. The null hypothesis of ANOVA (M) was there were no variations in selected wood anatomical parameters and specific gravity due to the fixed factors viz. radial location, peripheral direction, height, replication, clone and method of propagation. Finally, Variance ratio (F) test was used for the test of significance. The cluster analysis was done using SPSS 10 for wood anatomical properties and specific gravity.

\section{RESULTS}

Wood element's dimensions and specific gravity of selected clones of Populus deltoides propagated by macroand micro-propagation techniques and the results of Multivariate analysis are given in Table 2 to 9.

Table 2. Pith to periphery variations in wood element's dimensions $(\mu \mathrm{m})$ and specific gravity in micro and macro propagated wood (I = inner, $\mathrm{M}=$ middle, $\mathrm{O}$ = outer).

\begin{tabular}{|c|c|c|c|c|c|c|c|c|c|c|c|c|c|}
\hline Clone & Location & FL & SD & $\mathrm{FD}($ & $\mathrm{SD}$ & WT & SD & VL & SD & VD & SD & SG & SD \\
\hline \multirow{4}{*}{ L34 Macro } & I & 956.67 & 76.31 & 23.67 & 1.04 & 3.50 & 0.15 & 522.11 & 32.85 & 99.3 & 5.458 & 0.371 & 0.030 \\
\hline & M & 964.17 & 98.51 & 23.64 & 1.02 & 3.57 & 0.23 & 517.50 & 28.12 & 100.2 & 5.278 & 0.375 & 0.023 \\
\hline & $\mathrm{O}$ & 960.03 & 63.32 & 23.89 & 0.96 & 3.60 & 0.37 & 518.31 & 35.25 & 100.9 & 7.328 & 0.407 & 0.049 \\
\hline & Mean & 960.29 & 79.38 & 23.73 & 1.01 & 3.56 & 0.25 & 519.31 & 32.07 & 100.1 & 6.021 & 0.384 & 0.034 \\
\hline \multirow{4}{*}{ Micro } & I & 981.50 & 51.69 & 21.65 & 1.38 & 3.55 & 0.22 & 527.75 & 50.27 & 89.9 & 6.349 & 0.364 & 0.023 \\
\hline & M & 992.39 & 51.31 & 21.99 & 1.43 & 3.52 & 0.22 & 546.36 & 41.69 & 91.3 & 5.469 & 0.375 & 0.045 \\
\hline & $\mathrm{O}$ & 1015.33 & 94.93 & 22.10 & 1.36 & 3.59 & 0.25 & 557.94 & 43.12 & 91.6 & 6.685 & 0.399 & 0.041 \\
\hline & Mean & 996.41 & 65.98 & 21.91 & 1.39 & 3.55 & 0.23 & 544.02 & 45.03 & 90.9 & 6.168 & 0.379 & 0.037 \\
\hline \multirow{4}{*}{ G3 Macro } & I & 1032.19 & 78.04 & 23.31 & 1.28 & 3.82 & 0.43 & 536.67 & 45.72 & 98.1 & 8.726 & 0.395 & 0.031 \\
\hline & M & 1086.89 & 113.45 & 23.06 & 1.19 & 4.54 & 3.87 & 544.28 & 39.20 & 98.1 & 9.193 & 0.420 & 0.041 \\
\hline & $\mathrm{O}$ & 1106.33 & 127.11 & 23.22 & 1.20 & 3.87 & 0.43 & 557.17 & 40.46 & 101.6 & 10.327 & 0.417 & 0.041 \\
\hline & Mean & 1075.14 & 106.20 & 23.19 & 1.23 & 4.08 & 1.58 & 546.04 & 41.79 & 99.3 & 9.415 & 0.411 & 0.037 \\
\hline \multirow{4}{*}{ Micro } & I & 1080.69 & 134.24 & 23.72 & 1.73 & 3.96 & 0.47 & 578.78 & 32.82 & 96.2 & 8.255 & 0.336 & 0.025 \\
\hline & M & 1083.69 & 128.52 & 23.61 & 1.64 & 4.03 & 0.41 & 577.72 & 33.31 & 117.8 & 136.264 & 0.334 & 0.028 \\
\hline & $\mathrm{O}$ & 1073.11 & 112.39 & 23.44 & 1.78 & 4.01 & 0.40 & 572.75 & 32.67 & 95.0 & 13.624 & 0.366 & 0.027 \\
\hline & Mean & 1079.17 & 125.05 & 23.59 & 1.72 & 4.00 & 0.43 & 576.42 & 32.93 & 103.0 & 52.714 & 0.345 & 0.027 \\
\hline \multirow{4}{*}{ S7C17 Macro } & I & 1022.03 & 133.02 & 22.39 & 1.25 & 4.18 & 0.26 & 548.92 & 46.97 & 90.4 & 6.005 & 0.367 & 0.034 \\
\hline & M & 999.17 & 126.43 & 22.61 & 0.99 & 4.11 & 0.29 & 560.56 & 47.79 & 92.8 & 6.193 & 0.375 & 0.031 \\
\hline & $\mathrm{O}$ & 1009.67 & 129.90 & 22.64 & 1.27 & 4.14 & 0.35 & 552.75 & 47.49 & 91.9 & 4.281 & 0.405 & 0.032 \\
\hline & Mean & 1010.29 & 129.78 & 22.55 & 1.17 & 4.15 & 0.30 & 554.07 & 47.42 & 91.7 & 5.493 & 0.383 & 0.032 \\
\hline \multirow{4}{*}{ Micro } & I & 952.92 & 46.38 & 23.44 & 0.61 & 3.75 & 0.14 & 539.25 & 17.10 & 97.3 & 3.148 & 0.354 & 0.024 \\
\hline & M & 950.89 & 46.09 & 23.42 & 0.69 & 3.74 & 0.13 & 538.81 & 24.91 & 97.3 & 4.579 & 0.360 & 0.030 \\
\hline & $\mathrm{O}$ & 958.64 & 50.35 & 23.47 & 0.56 & 3.71 & 0.13 & 539.75 & 15.48 & 95.8 & 12.597 & 0.392 & 0.038 \\
\hline & Mean & 954.15 & 47.61 & 23.44 & 0.62 & 3.73 & 0.13 & 539.27 & 19.16 & 96.8 & 6.775 & 0.369 & 0.031 \\
\hline
\end{tabular}

Note: $\mathrm{FL}$ = fiber length, $\mathrm{FD}$ = fiber diameter, $\mathrm{WT}$ = wall thickness, $\mathrm{VL}$ = vessel element length, $\mathrm{VD}$ = vessel element diameter, $\mathrm{SG}=$ specific gravity. 


\subsection{Variations in Micro vs. Macro Propagated Wood}

\subsubsection{Variations for All Clones}

\subsubsection{Variation in Growth}

Variance ratio $(\mathrm{F})$ test indicated that variation in girth at breast height (gbh) was significant for clone, technique and height. The clone L34 showed the significantly higher girth followed by G3 and S7C15 clone. The girth (cm) was significantly higher in macro-propagated than micro-propagated ramets (Table 6). The girth significantly varied from bottom to top. The average girth $(\mathrm{cm})$ of 3 clones at selected height was in D1 (77.39), D2 (61), D3 (55.78) and D4 (46.72).

\subsubsection{Variation in Wood Anatomical Parameters and Specific Gravity}

Variance ratio (F) test indicated that intra-ramet variations were non-significant for all the characters except specific gravity for height in L34 for macro and specific gravity and vessel element diameter for radial locations for micro, and fiber length for G3 (micro) for height, and specific gravity for location and fiber length for height in S7C15 clone for both the techniques (Table 5) while inter-clonal variations were significant for fiber length, fiber diameter, wall thickness and vessel element length. The variations were significant for techniques (micro and macro-propagated) for vessel element length and specific gravity. Intra-clonal variations were significant for fiber length, fiber diameter and vessel element length (Table 6). In general wood element's dimensions and specific gravity increased from bottom to top and pith to periphery locations (Table 2 and 3). The average values of all the clones indicated that wall thickness and specific gravity were higher in macro-propagated wood while fiber length and vessel element length in micro-propagated wood. The range was $954 \mu \mathrm{m}$ (S7C15, micro)-1079 $\mu \mathrm{m}$ (G3, micro) for fiber length; $21.91 \mu \mathrm{m}$ (L34, micro)-23.73 $\mu \mathrm{m}$ (L-34, macro) for fiber diameter; $3.55 \mu \mathrm{m}$ ((L34, micro)-4.15 $\mu \mathrm{m}$ (S7C15, macro) for wall thickness; $519 \mu \mathrm{m}$ (L-(L34, macro) - $575 \mu \mathrm{m}$ (G3, micro) for vessel element length; $92 \mu \mathrm{m}$ (S7C15, macro) $103 \mu \mathrm{m}$ (G3, micro) and 0.345 (G3, micro)-0.411 (G3, macro) (Table 5). The grouping of different clones for fiber length was (S7C15-micro, L34-macro), (L34-micro, L34-macro), (L34-micro, S7C15-macro), (G3-macro, G3-micro); for fiber diameter was (L34-micro), (S7C15-macro), (G3-macro, S7C15-micro, L34-macro) for wall thickness was (L34-micro, L-34 macro, S7C15-micro), (G3-micro, G3-macro, S7C15-macro); for vessel element length was (L34-macro), (G3-macro), (S7C15-micro, L34-micro, G3-macro, S7C15-macro) and for specific gravity was (G3-micro), (S7C15-micro,
L34-micro, S7C15-macro), (L34-macro, S7C15-macro, L34-macro) and (G3-micro). The percent co-variance indicated that there was not much difference between variation pattern of micro and macro propagated plantation wood (Table 4).

\subsubsection{Variations in Individual Clones}

\subsubsection{L-34 Clone}

Variations in wood element's dimensions between micro and macro propagated plantation's wood were significant for fiber length, fiber diameter, vessel element length and vessel element diameter; fiber length, fiber diameter, wall thickness and vessel element diameter for replication; vessel element diameter for bottom to top; fiber length for peripheral direction and specific gravity for radial locations. Fiber length and vessel element length were significantly higher in micro-propagated wood while fiber diameter and vessel element diameter were significantly higher in macro-propagated wood (Table 7). Bottom to top variation for fiber length ranged between $935 \mu \mathrm{m}$ (D3) to $985 \mu \mathrm{m}$ and specific gravity ranged between 0.367 (D1) to $0.392 \mu \mathrm{m}$ (Table 3).

\subsubsection{G3 Clone}

Variations between micro- and macro-propagated plantation's wood were significant for vessel element length and specific gravity; fiber length, fiber diameter and vessel element length for replication; vessel element length and specific gravity for bottom to top and specific gravity for radial locations. Vessel element length was significantly higher for micro-propagated wood while specific gravity for macro- propagated wood (Table 8). Bottom to top variation for fiber length ranged between $1053.67 \mu \mathrm{m}$ (D2)-1122. $41 \mu \mathrm{m}$ (D1) (Table 3).

\subsubsection{S7 C15 Clone}

Fiber length, fiber diameter, wall thickness and vessel element length significantly varied between micro- and macro-propagated plantation's wood; fiber length, wall thickness, vessel element length and specific gravity for replication; fiber length for bottom to top and specific gravity for radial locations. Fiber length, wall thickness and vessel element length was significantly higher in macro-propagated wood whereas fiber diameter in micro propagated wood (Table 4 and 9). Bottom to top variation for fiber length ranged between $958 \mu \mathrm{m}$ (D3) to $1053.37 \mu \mathrm{m}$ (D1).

\subsection{Variations in Macro Propagated Wood}

\subsubsection{Variations in All Clones}

Variations in all wood elements' dimensions were significant for clones; fiber length, fiber diameter, vessel element length and specific gravity for replication; fiber length and specific gravity for bottom to top and for radial 
Table 3. Bottom to top variations in wood element's dimensions $(\mu \mathrm{m})$ and specific gravity (D1 bottom disc and D2, D3, and D4 are 4 successive discs at the $2.5 \mathrm{~m}$ intervals).

\begin{tabular}{|c|c|c|c|c|c|c|c|c|c|c|c|c|c|}
\hline \multirow[b]{2}{*}{ Parameter/Clone } & \multicolumn{7}{|c|}{ Macro } & \multicolumn{6}{|c|}{ Micro } \\
\hline & & FL & FD & WT & VL & VD & SG & FL & FD & WT & VL & VD & SG \\
\hline \multirow{3}{*}{ D } & Mean & 973.52 & 23.56 & 3.47 & 514.04 & 100.56 & 0.38 & 981.67 & 21.56 & 3.63 & 531.30 & 91.15 & 0.367 \\
\hline & SD & 73.26 & 0.91 & 0.18 & 29.83 & 3.38 & 0.04 & 63.82 & 1.55 & 0.21 & 36.03 & 3.12 & 0.028 \\
\hline & Mean & 946.63 & 24.11 & 3.53 & 517.11 & 101.74 & 0.38 & 1011.44 & 21.67 & 3.52 & 550.67 & 93.52 & 0.375 \\
\hline \multirow{2}{*}{ L 34} & SD & 58.16 & 1.22 & 0.22 & 32.77 & 4.09 & 0.03 & 101.44 & 1.42 & 0.29 & 44.62 & 7.77 & 0.030 \\
\hline & Mean & 935.37 & 23.84 & 3.61 & 524.37 & 100.33 & 0.38 & 1002.70 & 22.09 & 3.53 & 549.67 & 88.07 & 0.383 \\
\hline \multirow{2}{*}{ D3 } & SD & 49.58 & 0.58 & 0.37 & 30.93 & 8.78 & 0.04 & 56.51 & 1.50 & 0.19 & 65.32 & 6.76 & 0.030 \\
\hline & Mean & 985.63 & 23.43 & 3.61 & 521.70 & 97.78 & 0.39 & 989.81 & 22.32 & 3.53 & 544.44 & 91 & 0.392 \\
\hline D4 & SD & 115.94 & 1.09 & 0.26 & 34.93 & 6.15 & 0.05 & 44.67 & 0.94 & 0.20 & 32.94 & 5.061 & 0.061 \\
\hline Mean & & 960.29 & 23.73 & 3.56 & 519.31 & 100.10 & 0.38 & 996.41 & 21.91 & 3.55 & 544.02 & 90.935 & 0.379 \\
\hline SD & & 74.24 & 0.95 & 0.25 & 32.11 & 5.60 & 0.04 & 66.61 & 1.35 & 0.22 & 44.73 & 5.679 & 0.037 \\
\hline \multirow{3}{*}{ D1 } & Mean & 1063.89 & 23.41 & 3.74 & 557.93 & 103.30 & 0.38 & 1103.22 & 23.26 & 4.14 & 589.59 & 101.481 & 0.326 \\
\hline & SD & 107.92 & 1.45 & 0.44 & 39.29 & 13.07 & 0.03 & 156.96 & 0.86 & 0.28 & 31.91 & 18.404 & 0.020 \\
\hline & Mean & 1053.67 & 23.22 & 3.94 & 552.67 & 97.89 & 0.40 & 1110.37 & 23.33 & 4.2 & 574.78 & 95.667 & 0.359 \\
\hline D2 & SD & 82.43 & 1.15 & 0.19 & 34.10 & 6.13 & 0.04 & 139.04 & 1.14 & 0.29 & 39.64 & 5.657 & 0.025 \\
\hline \multirow{2}{*}{ D3 } & Mean & 1060.59 & 22.81 & 4.76 & 527.07 & 96.41 & 0.43 & 1056.85 & 24.04 & 3.82 & 572.48 & 92.481 & 0.352 \\
\hline & SD & 122.33 & 1.27 & 4.46 & 47.39 & 9.89 & 0.04 & 101.23 & 2.46 & 0.61 & 30.20 & 6.435 & 0.033 \\
\hline \multirow{2}{*}{ D4 } & Mean & 1122.41 & 23.33 & 3.87 & 546.48 & 99.41 & 0.43 & 1046.22 & 23.74 & 3.85 & 568.81 & 122.296 & 0.345 \\
\hline & SD & 121.69 & 0.92 & 0.61 & 43.19 & 6.15 & 0.03 & 78.15 & 1.87 & 0.31 & 25.46 & 157.546 & 0.032 \\
\hline Mean & & 1075.14 & 23.19 & 4.08 & 546.04 & 99.25 & 0.41 & 1079.17 & 23.59 & 4.00 & 576.42 & 102.981 & 0.345 \\
\hline SD & & 108.59 & 1.20 & 1.43 & 40.99 & 8.81 & 0.03 & 118.85 & 1.58 & 0.37 & 31.80 & 47.011 & 0.028 \\
\hline \multirow{3}{*}{ D1 } & Mean & 1053.37 & 22.44 & 4.11 & 545.33 & 89.41 & 0.37 & 962.67 & 23.33 & 3.66 & 532.59 & 96.519 & 0.355 \\
\hline & SD & 171.31 & 1.09 & 0.37 & 46.65 & 6.46 & 0.04 & 32.41 & 0.68 & 0.12 & 11.28 & 4.173 & 0.031 \\
\hline & Mean & 1052.37 & 22.70 & 4.16 & 549.11 & 91.30 & 0.39 & 967.44 & 23.44 & 3.71 & 534.78 & 97.963 & 0.366 \\
\hline D2 & SD & 159.98 & 1.35 & 0.32 & 59.90 & 7.16 & 0.04 & 49.20 & 0.51 & 0.11 & 23.40 & 3.436 & 0.033 \\
\hline \multirow{2}{*}{ D3 } & Mean & 958.63 & 22.30 & 4.09 & 550.33 & 92.04 & 0.38 & 969.07 & 23.44 & 3.76 & 548.22 & 99.222 & 0.380 \\
\hline & SD & 65.84 & 1.27 & 0.23 & 33.61 & 3.09 & 0.03 & 52.45 & 0.75 & 0.12 & 21.25 & 4.003 & 0.037 \\
\hline \multirow{2}{*}{ D4 } & Mean & 976.78 & 22.74 & 4.21 & 571.52 & 93.96 & 0.39 & 917.41 & 23.56 & 3.80 & 541.48 & 93.481 & 0.374 \\
\hline & SD & 37.87 & 0.94 & 0.26 & 43.01 & 3.92 & 0.04 & 33.14 & 0.51 & 0.14 & 16.43 & 13.891 & 0.036 \\
\hline Mean & & 1010.29 & 22.55 & 4.15 & 554.07 & 91.68 & 0.38 & 954.15 & 23.44 & 3.73 & 539.27 & 96.796 & 0.369 \\
\hline SD & & 108.75 & 1.16 & 0.30 & 45.79 & 5.16 & 0.04 & 41.80 & 0.61 & 0.123014 & 18.09 & 6.376 & 0.034 \\
\hline
\end{tabular}

Note: FL = fiber length, FD = fiber diameter, $\mathrm{WT}=$ wall thickness, $\mathrm{VL}=$ vessel element length, $\mathrm{VD}=$ vessel element diameter, $\mathrm{SG}=$ specific gravity. 
Table 4. Mean \pm SD for wood element's dimensions ( $\mu \mathrm{m})$ and specific gravity.

\begin{tabular}{|c|c|c|c|c|c|c|c|}
\hline \multicolumn{2}{|c|}{ Parameter/Clone } & FL & FD & WT & $\mathrm{VL}$ & VD & SG \\
\hline \multirow{4}{*}{ Macro } & Mean & 960 & 24 & 3.56 & 519 & 100 & 0.384 \\
\hline & SD & 80 & 1 & 0.27 & 32.0 & 6.1 & 0.039 \\
\hline & $\% \mathrm{CV}$ & 8 & 4 & 8 & 6 & 6 & 10 \\
\hline & Mean & 996 & 22 & 3.55 & 544 & 91 & 0.379 \\
\hline \multirow[t]{3}{*}{ Micro } & SD & 70 & 1 & 0.23 & 46 & 6 & 0.040 \\
\hline & $\% \mathrm{CV}$ & 7 & 6 & 6 & 9 & 7 & 11 \\
\hline & Mean & 1075 & 23 & 4.08 & 546 & 99 & 0.411 \\
\hline \multirow[t]{3}{*}{ Macro } & SD & 112 & 1 & 2.27 & 42 & 9 & 0.039 \\
\hline & $\% \mathrm{CV}$ & 10 & 5 & 56 & 8 & 10 & 9 \\
\hline & Mean & 1079 & 24 & 4.00 & 576 & 103 & 0.345 \\
\hline \multirow{3}{*}{ Micro } & SD & 124 & 2 & 0.42 & 33 & 11 & 0.030 \\
\hline & $\% \mathrm{CV}$ & 12 & 7 & 11 & 6 & 11 & 9 \\
\hline & Mean & 1010 & 23 & 4.15 & 554 & 92 & 0.383 \\
\hline \multirow{3}{*}{ S7C15 } & SD & 129 & 1 & 0.30 & 47 & 6 & 0.036 \\
\hline & $\% \mathrm{CV}$ & 13 & 5 & 7 & 9 & 6 & 9 \\
\hline & Mean & 954 & 23 & 3.73 & 539 & 97 & 0.369 \\
\hline \multirow[t]{2}{*}{ Micro } & SD & 47 & 1 & 0.13 & 19 & 8 & 0.035 \\
\hline & $\% \mathrm{CV}$ & 5 & 3 & 4 & 4 & 8 & 10 \\
\hline
\end{tabular}

Note: $\mathrm{FL}=$ fiber length, $\mathrm{FD}=$ fiber diameter, $\mathrm{WT}=$ wall thickness, $\mathrm{VL}=$ vessel element length, $\mathrm{VD}$ = vessel element diameter, $\mathrm{SG}=$ specific gravity, $\mathrm{SD}=$ standard deviation, $\mathrm{CV}=$ covariance.

direction (Table 6). The range was $960 \mu \mathrm{m}$ (L34) - 1075 $\mu \mathrm{m}$ (G3) for fiber length; $22.55 \mu \mathrm{m}$ (S7C15) - 23.73 (L34) for fiber diameter; $3.56 \mu \mathrm{m}$ (L34) $-4.15 \mu \mathrm{m}$ (S7C15) for wall thickness; $519 \mu \mathrm{m}$ (L34) $-554 \mu \mathrm{m}$ (S7C15) for vessel element length; $91.68 \mu \mathrm{m}$ (S7C15) $100.10 \mu \mathrm{m}$ (L34) for vessel element diameter and 0.38 (S7C15) - 0.41 (G3) for specific gravity. The percent variations were recorded for 8 (L34) - 13 (S7C15) for fiber length; 7 (S7C15) -56 (G3) for wall thickness; 6 (L34)-9 (S7c15) for vessel element length and 6 (L34)10 (S7C15) for vessel element diameter (Table 4). It showed that clones and replicate ramets showed variations in the wood element dimensions and specific gravity.

\subsubsection{Variations in Individual Clones}

\subsubsection{L-34 Clone}

Variations were significant for fiber length, wall thickness and vessel element length for replication; fiber length for bottom to top and specific gravity for radial locations (Table 7). The pith to periphery variations were ranged between $957 \mu \mathrm{m}$ (pith) - $964 \mu \mathrm{m}$ (middle) for fiber length; $23.64 \mu \mathrm{m}$ (middle) - $23.89 \mu \mathrm{m}$ (outer) for fiber diameter; $3.50 \mu \mathrm{m}$ (pith) $-3.60 \mu \mathrm{m}$ (outer) for wall thickness and 0.371 (pith) -0.407 (outer) for specific gravity.

\subsubsection{G3 Clone}

Variations were significant for fiber length, fiber diameter, vessel element length, vessel element diameter and specific gravity for replication; fiber length and specific gravity from bottom to top and fiber length and specific gravity for radial locations (Table 8). The pith to periphery variations were ranged between $1032 \mu \mathrm{m}$ (pith) $1106 \mu \mathrm{m}$ (outer) for fiber length and 0.395 (pith) -0.42 (middle) for specific gravity (Table 2).

\subsubsection{S7 C15 Clone}

Variations were significant for all the characters except vessel element diameter for replication; fiber length for bottom to top and specific gravity for radial locations (Table 9). The pith to periphery variations were ranged between 0.367 (pith) -0.405 for specific gravity (outer) (Table 2).

\subsection{Variations in Micro Propagated Wood}

\subsubsection{Variations in All Clones}

Fiber length, fiber diameter, wall thickness, vessel element length and specific gravity significantly varied for clones; fiber length, fiber diameter and vessel element length for replication; fiber length and specific gravity for bottom to top; fiber length and specific gravity for peripheral direction and specific gravity for radial locations in micro propagated trees (Table 6). The range was $954 \mu \mathrm{m}$ (S7C15) - $1079 \mu \mathrm{m}$ (G3) for fiber length; 21.91 $\mu \mathrm{m}$ (G3)-23.59 (G3) for fiber diameter; $3.55 \mu \mathrm{m}$ (L34) $4.0 \mu \mathrm{m}$ (G3) for wall thickness; $539 \mu \mathrm{m}$ (S7C15) - 546 $\mu \mathrm{m}$ (G3) for vessel element length; $90.94 \mu \mathrm{m}$ (L34) $102.98 \mu \mathrm{m}$ (G3) for vessel element diameter and 0.35 (G3) - 0.379 (L34) for specific gravity. The percent variations were recorded for 5 (S7C15) - 12 (G3) for fiber length; 4 (S7C15) - 11 (G3) for wall thickness; 4 (S7C15)-9 (L34); 6 (L34)-11 (G3) for vessel element length (Table 4). It shows that variations in wood element dimensions have not much difference among different clones.

\subsubsection{Variations in Individual Clones}

3.3.2.1. L-34 Clone

Variations were significant for fiber length and vessel element diameter for replication; vessel element diameter for bottom to top; fiber length for peripheral direction and specific gravity for radial locations (Table 7). The 
Table 5. Intra-ramet variations in different clones.

\begin{tabular}{|c|c|c|c|c|c|c|c|}
\hline \multirow{2}{*}{\multicolumn{2}{|c|}{$\begin{array}{c}\text { Wood parameters/Source of } \\
\text { variation }\end{array}$}} & \multicolumn{6}{|c|}{ MSS } \\
\hline & & \multirow[t]{2}{*}{ FL } & \multirow[t]{2}{*}{ FD } & \multirow[t]{2}{*}{ WT } & \multirow[t]{2}{*}{ VL } & \multirow[t]{2}{*}{ VD } & \multirow[t]{2}{*}{ SG } \\
\hline L34 (Macro) & $\mathrm{df}$ & & & & & & \\
\hline Height & 3 & 2164.9 & .674 & 0.023 & 1359. & 49.43 & $0.019 *$ \\
\hline Direction & 2 & 70.194 & .399 & 0.026 & 939.194 & 22.861 & 0.0027 \\
\hline Location & 2 & 569.7 & 0.49 & 0.011 & 2531.028 & 42.52 & 0.013 \\
\hline Error & 28 & 732.7 & .821 & 0.022 & 440.7 & 47.63 & 0.0011 \\
\hline \multicolumn{8}{|l|}{ Micro } \\
\hline Height & 3 & 20288.102 & 4.472 & 0.0037 & 12200.2 & 313.963* & 0.00073 \\
\hline Direction & 2 & 10802.7 & .778 & 0.0044 & 5909.361 & 121.194 & 0.00028 \\
\hline Location & 2 & 13268.528 & 1.194 & 0.017 & 13022.528 & 75.444 & $0.0073^{*}$ \\
\hline Error & 28 & 4856.627 & 1.748 & 0.056 & 3297.9 & 28.835 & 0.0005 \\
\hline \multicolumn{8}{|l|}{ G3 (Macro) } \\
\hline Height & 3 & 1939.282 & 1.010 & 0.01 & 225.896 & 15.136 & 0.004 \\
\hline Direction & 2 & 1073.740 & .201 & 0.036 & 3052.917 & 81.419 & 0.0005 \\
\hline Location & 2 & 2040.307 & 0.034 & 0.016 & 135.816 & 11.857 & 0.0045 \\
\hline Error & 28 & 1414.5 & .624 & 0.018 & 1053.674 & 16.717 & 0.0015 \\
\hline \multicolumn{8}{|l|}{ Micro } \\
\hline Height & 3 & $3607.9 *$ & .546 & 0.026 & 2924.667 & 4.963 & 0.0013 \\
\hline Direction & 2 & 201.083 & 0.028 & 0.007 & 330.333 & 13.000 & 0.0016 \\
\hline Location & 2 & 172.583 & .361 & 0.014 & 193.750 & 21.000 & 0.0029 \\
\hline Error & 28 & 364.9 & .329 & 0.021 & 811.637 & 10.040 & 0.00065 \\
\hline \multicolumn{8}{|c|}{ S7C15 (Macro) } \\
\hline Height & 3 & $282340.76^{*}$ & 3.630 & .253 & 2262.7 & 46.222 & 0.0027 \\
\hline Direction & 2 & 11651.083 & .194 & 0.019 & 1954.694 & 17.028 & 0.00051 \\
\hline Location & 2 & 6129.250 & .778 & 0.025 & 3497.861 & 104.111 & $0.0066^{*}$ \\
\hline Error & 28 & 4930.635 & 1.312 & 0.038 & 2212.048 & 51.069 & 0.001 \\
\hline \multicolumn{8}{|l|}{ Micro } \\
\hline Height & 3 & $9797.407 *$ & .324 & 0.05 & 1324.917 & 15.435 & 0.00085 \\
\hline Direction & 2 & 2315.444 & .361 & 0.0036 & 839.250 & 29.694 & 0.00022 \\
\hline Location & 2 & 920.111 & 0.028 & 0.00028 & 59.250 & 6.194 & $0.013^{*}$ \\
\hline Error & 28 & 1137.889 & .377 & 0.011 & 282.393 & 14.984 & 0.00010 \\
\hline
\end{tabular}

$* \mathrm{P}<0.001$. Note: $\mathrm{FL}=$ fiber length, $\mathrm{FD}=$ fiber diameter, $\mathrm{WT}=$ wall thickness, $\mathrm{VL}=$ vessel element length, $\mathrm{VD}=$ vessel element diameter, $\mathrm{SG}=$ specific gravity. 
Table 6. ANOVA for wood element's dimensions and specific gravity in macro and micro propagated wood.

\begin{tabular}{|c|c|c|c|c|c|c|c|c|}
\hline \multirow{2}{*}{\multicolumn{2}{|c|}{$\begin{array}{c}\text { Wood parameter/Source of } \\
\text { variation }\end{array}$}} & \multicolumn{7}{|c|}{ MSS } \\
\hline & & \multirow[t]{2}{*}{ FL } & \multirow[t]{2}{*}{ FD } & \multirow[t]{2}{*}{ WT } & \multirow[t]{2}{*}{ VL } & \multirow[t]{2}{*}{ VD } & \multirow[t]{2}{*}{ SG } & \multirow[t]{2}{*}{ gbh } \\
\hline Macro vs micro & df & & & & & & & \\
\hline Clone & 2 & $676447.0^{*}$ & $17.2^{*}$ & $14.1^{*}$ & 47203.9* & 2890.9 & 0.0019 & $3862.3^{*}$ \\
\hline Technique & 1 & 4602.7 & 3.99 & 4.3 & $29214.8^{*}$ & 1.8 & $0.126^{*}$ & $3784.5^{*}$ \\
\hline Replication & 2 & $445736.2 *$ & $58.5^{*}$ & 0.463 & $15763.9 *$ & 316.9 & 0.0034 & 29.2 \\
\hline Height & 3 & 27393.7 & 1.4 & 0.565 & 529.6 & $674.5^{*}$ & 0.019 & $2983.8^{*}$ \\
\hline Direction & 2 & 12263.9 & 0.344 & 1.40 & 3238.25 & 950.67 & 0.0019 & \\
\hline Location & 2 & 14159.8 & 0.628 & 0.922 & 3231.35 & 1148.6 & $0.064 *$ & \\
\hline Error & 740 & 8542.8 & 1.69 & 0.93 & 1488.9 & 1099.5 & 0.0012 & 79.7 \\
\hline \multicolumn{9}{|l|}{ Macro } \\
\hline Clone & 2 & $358140.8^{*}$ & $38.1^{*}$ & $11.23^{*}$ & $35784.3^{*}$ & $2323.6^{*}$ & $0.026^{*}$ & \\
\hline Replication & 2 & $251225.5^{*}$ & $22.54 *$ & 0.920 & $37336.0 *$ & 230.5 & $0.012 *$ & \\
\hline Height & 3 & 35733.2 & 1.76 & 2.11 & 2182.41 & 30.20 & $0.012^{*}$ & \\
\hline Direction & 2 & 4675.1 & 0.017 & 3.047 & 2089.4 & 27.0 & 0.00036 & \\
\hline Location & 2 & 12912.2 & 0.70 & 1.79 & 1340.7 & 134.45 & $0.023^{*}$ & \\
\hline Error & 312 & 10109.9 & 1.16 & 1.76 & 1448.46 & 51.53 & 0.00112 & \\
\hline \multicolumn{9}{|l|}{ Micro } \\
\hline Clone & 2 & $436762.3^{*}$ & $93.77^{*}$ & $5.47^{*}$ & 44139.37* & 3919.0 & $0.032 *$ & \\
\hline Replication & 2 & $268891.7^{*}$ & $45.75^{*}$ & 0.081 & 5884.08 & 635.6 & 0.006 & \\
\hline Height & 3 & $29046.5^{*}$ & 5.212 & 0.255 & 532.2 & 1178.4 & $0.0085 *$ & \\
\hline Direction & 2 & 10308.5 & 0.753 & 0.085 & 4454.5 & 2138.0 & 0.0058* & \\
\hline Location & 2 & 3134.7 & 0.162 & 0.012 & 1916.64 & 2206.15 & $0.037^{*}$ & \\
\hline Error & 312 & 5651.8 & 1.44 & 0.082 & 1153.64 & 2140.64 & 0.00093 & \\
\hline
\end{tabular}

$* \mathrm{P}<0.001$. Note: $\mathrm{FL}=$ fiber length, $\mathrm{FD}=$ fiber diameter, $\mathrm{WT}=$ wall thickness, $\mathrm{VL}=$ vessel element length, $\mathrm{VD}=$ vessel element diameter, $\mathrm{SG}=\mathrm{specific}$ gravity.

pith to periphery variations were ranged between 0.364 (pith) -0.399 for specific gravity (outer) (Table 2).

\subsubsection{G3 Clone}

Fiber length, fiber diameter and vessel element length were significantly varied in replication; fiber length, wall thickness and specific gravity from bottom to top and specific gravity in radial locations (Table 8). The pith to periphery variations were ranged between 0.336 (pith) -0.366 for specific gravity (outer) (Table 2 ).

\subsubsection{S7 C15 Clone}

Variations were significant only for fiber length for replications; fiber length, wall thickness and vessel element length for bottom to top; vessel length for radial direction and specific gravity for radial location (Table 9). The pith to periphery variations were ranged between 0.354 (pith) -0.392 for specific gravity (outer).

\subsection{Cluster Analysis}

Hierarchical cluster analysis was done using 'Squared Euclidean Distance' for the three clones grown by two techniques. Dendrogram using average linkage (between groups) was made for different clones considering all studied wood traits (Figure 1). G3 clone was divergent with other clones. L34 (micro) and S7C15 (macro) was different from L34 (macro) and S7C15 (micro) at 6 
Table 7. ANOVA for wood element's dimensions and specific gravity in macro and micro propagated wood of L34 clone.

\begin{tabular}{|c|c|c|c|c|c|c|c|}
\hline \multirow{2}{*}{\multicolumn{2}{|c|}{$\begin{array}{c}\text { Wood parameters/Source of } \\
\text { variation }\end{array}$}} & \multicolumn{6}{|c|}{ MSS } \\
\hline & & FL & FD & WT & VL & VD & SG \\
\hline \multicolumn{8}{|l|}{ Macro vs micro } \\
\hline Technique & 1 & $70452.8^{*}$ & $168.6^{*}$ & 0.00012 & $32979.4^{*}$ & $4537.5^{*}$ & 0.0012 \\
\hline Replication & 2 & $66248.3^{*}$ & $18.6^{*}$ & $0.883^{*}$ & 4642.3 & $259.1^{*}$ & 0.00003 \\
\hline Height & 3 & 3161.1 & 0.89 & 0.027 & 2098.1 & $136.3^{*}$ & 0.003 \\
\hline Direction & 2 & $27175.2^{*}$ & 3.26 & 0.17 & 3639.2 & 94.02 & 0.001 \\
\hline Location & 2 & 6225.7 & 2.09 & 0.094 & 3137.57 & 52.78 & $0.026^{*}$ \\
\hline Error & 205 & 4870.94 & 1.32 & 0.053 & 1518.6 & 33.20 & 0.0013 \\
\hline \multicolumn{8}{|l|}{ Macro } \\
\hline Replication & 2 & $152521.40^{*}$ & 3.90 & $1.150^{*}$ & 18649.08* & 151.60 & 0.0021 \\
\hline Height & 3 & $14622.160^{*}$ & 2.50 & 0.126 & 575.80 & 75.12 & 0.00092 \\
\hline Direction & 2 & 7847.07 & 1.70 & 0.186 & 672.30 & 16.50 & 0.00053 \\
\hline Location & 2 & 508.07 & 0.700 & 0.083 & 218.40 & 24.30 & $0.014^{*}$ \\
\hline Error & 98 & 3256.80 & $.90^{*}$ & 0.045 & 700.00 & 34.04 & 0.0013 \\
\hline \multicolumn{8}{|l|}{ Micro } \\
\hline Replication & 2 & 8878.0 & $28.89 *$ & 0.183 & 1638.40 & 464.06* & 0.0017 \\
\hline Height & 3 & 4738.60 & 3.50 & 0.075 & 2143.22 & $134.20 *$ & 0.0030 \\
\hline Direction & 2 & 21377.30* & 1.444 & 0.0212 & 7611.70 & 108.60 & 0.0045 \\
\hline Location & 2 & 10738.30 & 2.00 & 0.045 & 8353.50 & 29.40 & 0.012 \\
\hline Error & 98 & 4350.4 & 1.345 & $0.050 *$ & 1933.01 & 25.245 & 0.0013 \\
\hline
\end{tabular}

$* \mathrm{P}<0.001$. Note: FL = fiber length, FD = fiber diameter, WT = wall thickness, VL = vessel element length, VD = vessel element diameter, SG $=$ specific gravity.

rescaled distance cluster combine. The wood properties of G3 clone were similar in the wood produced by two different techniques, whereas the L34 and S7C15 produced wood by two techniques showed variations in wood properties. It showed that G3 clone was stable whereas L34 and S7C15 showed variations in wood traits between the wood produced by two techniques.

\section{DISCUSSION}

Variance ratio $(\mathrm{F})$ test indicated that inter-clonal variations were non significant for all studied wood traits except wall thickness and fiber length for central block $(\mathrm{P}<0.001)$. Significant inter-clonal variations in wall thickness and vessel element length indicated that these traits had strong inheritance even at the early phase of the tree growth. The pooled data analysis of three clones indicated that fiber length, vessel element length and specific gravity were the wood traits which varied between macro- and micro-propagated wood of Populus deltoides clones (Table 6). Specific gravity and wall thickness were higher in macro-propagated wood while vessel element length in micro-propagated wood. The trend was more or less similar to individual clones. The grouping of different clones indicated that clones behave differently for different wood traits.

Significant inter-clonal variations were reported for fiber length, fiber diameter, fiber wall thickness, vessel element length and specific gravity. Significant differences among the different clonal ramets of different species in average fiber-length are also reported by many workers [7,9,10,13,14]. Cheng and Bensend [15], Einspahar et al. [16], Kennedy [17] and Peszlen [18] reported that fiber length is under genetic control. Clone to clone variations were also reported in Tectona grandis 
Table 8. ANOVA for wood element's dimensions and specific gravity in macro and micro propagated wood of G3 clone.

\begin{tabular}{|c|c|c|c|c|c|c|c|}
\hline \multirow{2}{*}{\multicolumn{2}{|c|}{$\begin{array}{c}\text { Wood parameter/Source of } \\
\text { variation }\end{array}$}} & \multicolumn{6}{|c|}{ MSS } \\
\hline & & \multirow[t]{2}{*}{ FL } & \multirow[t]{2}{*}{ FD } & \multirow[t]{2}{*}{ WT } & \multirow[t]{2}{*}{ VL } & \multirow[t]{2}{*}{ VD } & \multirow[t]{2}{*}{ SG } \\
\hline Macro vs micro & df & & & & & & \\
\hline Technique & 1 & 876.04 & 8.560 & .308 & $49837.80 *$ & 751.90 & $0.230^{*}$ \\
\hline Replication & 2 & 790333.80* & $84.60^{*}$ & 1.315 & $222478.70^{*}$ & 1959.40 & 0.0030 \\
\hline Height & 3 & $8201.70 *$ & $0.70 *$ & 1.9 & 5529.20 & 2875.30 & $0.016^{*}$ \\
\hline Direction & 2 & 9263.04 & 0.50 & 2.80 & 28.10 & 2520.06 & 0.000093 \\
\hline Location & 2 & 23510.40 & 0.80 & 3.24 & 945.30 & 2522.70 & $0.012^{*}$ \\
\hline Error & 205 & 6428.21 & 1.4 & 2.70 & 1185.9 & 3208 & 0.0009 \\
\hline \multicolumn{8}{|l|}{ Macro } \\
\hline Replication & 2 & $238056.80 *$ & $28.90^{*}$ & 4.54 & $15315.60 *$ & $702.90 *$ & $0.0072 *$ \\
\hline Height & 3 & $27301.70^{*}$ & 1.90 & 5.8 & 4905.80 & 237 & $0.015^{*}$ \\
\hline Direction & 2 & $6631.0^{*}$ & .111 & 6.80 & 795.90 & 72.30 & 0.00005 \\
\hline Location & 2 & 53196.90* & .60 & 5.80 & 3865.8 & 150.50 & $0.0066^{*}$ \\
\hline Error & 63 & 6712.60 & .96 & 5.09 & 1401.06 & 72.40 & 0.00092 \\
\hline \multicolumn{8}{|l|}{ Micro } \\
\hline Replication & 2 & 601137.7* & $61.80^{*}$ & $.50 *$ & 9300.25 & 3811.40 & 0.00082 \\
\hline Height & 3 & $28220.70^{*}$ & 3.60 & $1.03 *$ & 2246.08 & 4851.60 & $0.0056^{*}$ \\
\hline Direction & 2 & 8056.08 & 1.0 & .30 & 490.50 & 6263.20 & 0.0004 \\
\hline Location & 2 & 1071.08 & 0.704 & 0.039 & 373.03 & 5923.40 & $0.011^{*}$ \\
\hline Error & 63 & 3676.60 & 1.7 & .15 & 865.0 & 6411.20 & 0.00059 \\
\hline
\end{tabular}

${ }^{*} \mathrm{P}<0.001$. Note: $\mathrm{FL}=$ fiber length, $\mathrm{FD}=$ fiber diameter, $\mathrm{WT}=$ wall thickness, $\mathrm{VL}=$ vessel element length, $\mathrm{VD}=$ vessel element diameter, $\mathrm{SG}=\mathrm{specific}$ gravity.

for wood properties [19], in D. sissoo by Pande and Singh [20] and in Populus deltoides by Chauhan et al. [10]. Further, Veenin et al. [21] reported significant inter-clonal variation in wood anatomical properties and specific gravity in Eucalyptus camaldulensis. In the present study clone to clone variation in specific gravity was observed. Significant inter-clonal variations in specific gravity of Eucalyptus tereticornis at the one site was reported by Pande [22]. Significant differences in average specific gravity of different clones in the present study are also in agreement with the earlier findings in Populus spp. [7,9], in Eucalyptus tereticornis. [14] and in Dalbergia sissoo [20,23]. Specific gravity is moderately to strongly inherited trait and is under the influence of additive gene action in case of Tectona grandis [24].

Non-significant intra-clonal variations were reported by Pande and Singh [20] in D. sissoo and in E. tereticornis by Pande [22]. In contrary, present study showed significant intra-clonal variation in fiber length, fiber diameter, wall thickness, vessel element length and specific gravity in macro; fiber length, and fiber diameter and vessel element length in micro propagated plantation wood. It showed that with in clone variability is present among the clonal ramets of Populus deltoides. It showed that intra-clonal variations for different wood traits are varied differently for different species and clones.

Axial and horizontal (both peripheral and radial) in pooled data of all the clones were non-significant except specific gravity. But, the individual clone with micro- or macro-propagated method showed somewhat different trend. It showed non-significant variations in most of the cases except few sporadic exceptions. L34 clone showed axial variation for specific gravity in macro-propagated 
Table 9. ANOVA for wood element's dimensions and specific gravity in macro and micro propagated wood of S7C15 clone.

\begin{tabular}{|c|c|c|c|c|c|c|c|}
\hline \multirow{2}{*}{\multicolumn{2}{|c|}{$\begin{array}{c}\text { Wood parameter/Source of } \\
\text { variation }\end{array}$}} & \multicolumn{6}{|c|}{ MSS } \\
\hline & & \multirow[t]{2}{*}{ FL } & \multirow[t]{2}{*}{ FD } & \multirow[t]{2}{*}{ WT } & \multirow[t]{2}{*}{$\mathrm{VL}$} & \multirow[t]{2}{*}{ VD } & \multirow[t]{2}{*}{ SG } \\
\hline Macro vs micro & $\mathrm{df}$ & & & & & & \\
\hline Technique & 1 & $170185.04 *$ & $43.56^{*}$ & $9.16^{*}$ & $11837.04 *$ & 1415.78 & 0.01 \\
\hline Replication & 2 & $257777.42 *$ & 3.81 & $0.53^{*}$ & 11688.91* & 60.67 & $0.008^{*}$ \\
\hline Height & 3 & 54062.63* & 1.02 & 0.14 & 3332.86 & 71.67 & $0.005^{*}$ \\
\hline Direction & 2 & 6310.37 & 1.45 & 0.0003 & 21478.1 & 214.3 & 0.0001 \\
\hline Location & 2 & 2989.78 & 0.37 & 0.03 & 573.51 & 36.29 & $0.02 *$ \\
\hline Error & 205 & 6448.84 & 0.85 & 0.04 & 1178.12 & 46.85 & 0.0008 \\
\hline \multicolumn{8}{|l|}{ Macro } \\
\hline Replication & 2 & $327993.70^{*}$ & $12.30 *$ & $1.50^{*}$ & $27288.9 *$ & 132.23 & $0.011^{*}$ \\
\hline Height & 3 & $66766.80 *$ & 1.22 & 0.083 & 3774.0 & 95.90 & 0.0027 \\
\hline Direction & 2 & 2463.60 & 2.01 & 0.0056 & 1254.0 & 2.90 & 0.00083 \\
\hline Location & 2 & 4714.07 & 0.70 & 0.044 & 1266.50 & 53.80 & $0.014 *$ \\
\hline Error & 63 & 9267.01 & 1.20 & 0.064 & 1711.30 & 27.40 & 0.0008 \\
\hline \multicolumn{8}{|l|}{ Micro } \\
\hline Replication & 2 & 41614.80 & 0.75 & 0.053 & 151.70 & 1.12 & $0.0006^{*}$ \\
\hline Height & 3 & $16398.2^{*}$ & 0.22 & $0.098 *$ & $1348.2^{*}$ & 164.80 & 0.0031 \\
\hline Direction & 2 & 4518.40 & 0.36 & 0.0025 & $2088.8^{*}$ & 13.62 & 0.0025 \\
\hline Location & 2 & 581.50 & 0.027 & 0.010 & 8.04 & 26.60 & $0.014 *$ \\
\hline Error & 63 & 989.00 & 0.40 & 0.014 & 324.50 & 62.40 & 0.00089 \\
\hline
\end{tabular}

${ }^{*} \mathrm{P}<0.001$. Note: $\mathrm{FL}=$ fiber length, $\mathrm{FD}=$ fiber diameter, $\mathrm{WT}=$ wall thickness, $\mathrm{VL}=$ vessel element length, $\mathrm{VD}=$ vessel element diameter, $\mathrm{SG}=$ specific gravity.

Rescaled Distance Cluster Combine

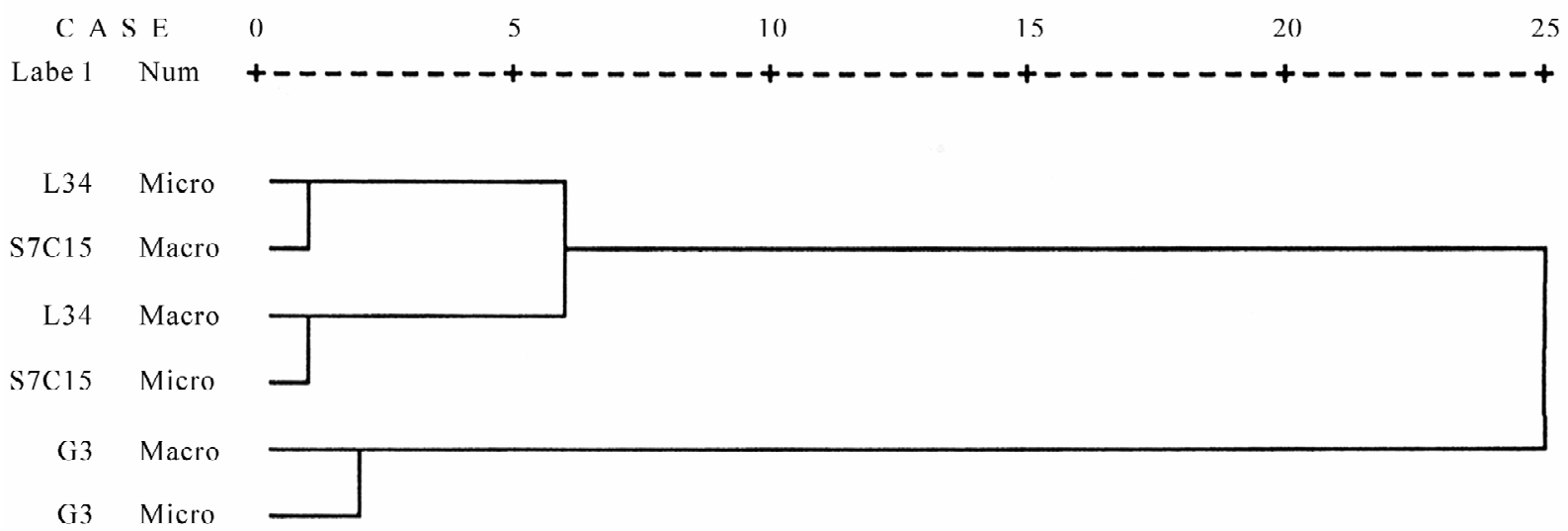

Figure 1. Dendrogram using the wood parameters for three clones with both macro and micro-propagation method. 
wood while for micro-propagated wood variations were for vessel element diameter and specific gravity. In G3 and S7C15 clone, axial variations were represented only for fiber length. Radial variation was only for specific gravity for all the clones. It showed that clones of Populus deltoides presented different patterns of within tree variations for different wood traits. Even the pattern was not same for individual clone grown by two different techniques. Significant radial variations for fiber length in some poplar clones were also recorded by Kaubaa et al. [8]; and in vessel lumen diameter and fiber length by Peszlen, [18]. In general, non-significant variations due to peripheral direction and radial location in wood element dimensions within a ramet and absence of any trend may be related to the early maturity of clone-raised tree. It appears that growing age may not have any impact on the wood element dimensions in clonal ramets of Populus deltoides even at the early phase of tree growth. Veenin et al. [21] also reported non-significant radial variations in fiber length, vessel element diameter and vessel density in clone raised ramets of $E$. camaldulensis. Such type of results were also reported in clonal plantation of Populus deltoides by Chauhan et al. [10]; Dalbergia sissoo by Pande and Singh [20] and in Eucalyptus tereticornis by Pande [22]. However, within tree axial and horizontal variations in wood element's dimension in seed raised trees of different species were reported $[6,11,14,25,26]$. In general, the increasing trend for specific gravity was observed from bottom to top and pith to periphery. However, radial variations in specific gravity in E. camaldulensis are reported by Veenin et al. [21]. In Tectona grandis, the density increased towards the peripheral direction by 5-6 cm from the pith which stabilizes by the age of 10-12 years [27]. In the case of Dalbergia sissoo and other clones of Populus deltoides, there was non-significant pith to periphery radial variations and no specific trend was observed for specific gravity $[10,20]$. Thus, the trends can be different from one species to another.

\section{CONCLUSIONS}

Populus deltoides clones showed differential pattern of variability for different wood traits. The three different clones of Populus deltoides showed variability in wood anatomical properties in the woods of micro- and macro-propagated plantation. So, the plantation raised by two techniques could not produced similar type of wood even from the same clone. G3 clone was the exception as it did not show variations in wood traits for two techniques.

In general, the higher specific gravity and fiber wall thickness can be obtained by growing the plantation of this species by macro-propagation techniques.
Variations are observed in fiber dimensions in macropropagated wood of all three clones. G3 clone is stable for wood traits as it showed similar type of wood propertied in the wood grown by the two techniques. Further, it showed higher fiber dimensions and specific gravity than of the other clones.

Intra-clonal variations in all the three clones of Populus deltoides indicated that wood traits were not stable within the population of same clone grown by either method.

Non-significant intra-ramet variation in wood anatomical characteristics in both the techniques indicated narrow juvenile wood zone and may form mature wood even at the early phase of tree growth.

\section{ACKNOWLEDGEMENTS}

Acknowledgements are also due to Director, Forest Research Institute, Dehradun (India) for providing necessary facilities during the work. Author is also thankful to Mr. G. S. Bisht, Research Assistant, Wood anatomy Discipline, Forest Research Institute, Dehradun for laboratory-assistance and Mr. J N Gandhi of Wimco Ltd. for field work.

\section{REFERENCES}

[1] Dadswell, H.E. (1957) Tree growth characteristics and their influence on wood structure and properties. Proceedings of 7th British Commonwealth Forestry Conference, CSIRO, Australia, 1957.

[2] Burley, J. and Palmer, R.R. (1979) Pulp and wood densitometric properties of Pinus caribaea from Fiji. Commonwealth Forestry Institute Occasional Paper, 66.

[3] Dinwoodie, J.M. (1961) Tracheid and fiber-length in timber. A review of literature. Forestry, 34, 124-144.

[4] Zobel, B. (1965) Inheritance of fiber characteristics and specific gravity in hardwoods-a review. Proceedings of the Meeting of Section 41 Meet, IUFRO, Melbourne, Australia, 1965.

[5] Rao, B.S.S. and Rao, R.V. (1978) Variation in length of vertical elements within one tree of betula pubercens ehrh. Journal of Indian Academy of Wood Science, 9(2), 105-110.

[6] Pande, P.K., Rao, R.V., Agrawal, S.P. and Singh, M. (1995) Variation in the dimensions of trachied elements of Pinus caribaea var. bahamensis. Journal of Tropical Forest Products, 1(2), 117-123.

[7] Phelps, J.E., Isebrands, J.G. and Jowett, D. (1982) Raw material quality of short rotation intensively cultured Populus clones. A comparison of stem and branches properties at three species. IAWA Journal, 3(3-4), 193200.

[8] Kaubaa, A., Hernandez, A.E., Beaudoin, M. and Poliquin, J. (1998) Interclonal, intra-clonal and within tree variation in fiber-length of Popular hybrid clones. Wood and Fiber science, 30(1), 1998, 140-147.

[9] Chauhan, L., Raturi, R.D. and Gupta, S. (1999) Studies on anatomical variations in different clones of Populus deltoides. Indian Forester, 125, 526-532. 
[10] Chauhan, L., Gupta, L.S., Madhwal, R.C., Pandey, R. and Pal, M. (2001) Interclonal, intraclonal and within tree variation in wood parameters of different clones of Populus deltoids. Indian Forester, 127(7), 777-784.

[11] Purkayastha, S.K., Agrawal, S.P., Farooqui, P., Tandon, R.D., Chauhan, L. and Misra, N. (1979) Evaluation of wood quality of Eucalyptus plantations in various states, Final Technical Report, (Nov. 1 to Oct. 31, 1979) PL 480 Project no Inn FS-66, 85, 1979-1980.

[12] IAWA Committee IAWA (1989) List of microscopic features for hardwood identification. IAWA Bulletin, 10(3), 201-232.

[13] Murphey, W.K., Bowersox, T.W. and Blankenhorn, P.R. (1979) Selected wood properties of young Populus hybrid. Wood Science, 11(4), 236-267.

[14] Rao, R.V., Shashikala, S., Sreevani, P., Kothiyal, V., Sharma, C.R. and Lal, P. (2002) Within tree variation in anatomical properties of some clones of Eucalyptus tereticornis Sm. Wood Science Technology, 36(3), 271-285.

[15] Cheng, W.W. and Bensend, D.W. (1979) Anatomical properties of selected Populus clones grown under intensive culture. Wood Science, 11(3), 182-187.

[16] Einspahr, D.W., Van Buijtenen, J.P. and Peckham, J.R (1963) Natural variation and heritability in triploid aspen. Silvae Genetica, 12(2), 51-58.

[17] Kennedy, R.W. (1968) Anatomy and fundamental wood properties of poplar. In: Maini J.S. and Cayford J.S. Eds., Growth and utilization of poplars in Canada, Canadian Department for Rural development, Forestry Branch, publication 1025, Canada, 149-168.

[18] Peszlen, I. (1994) Influence of age on selected anatomical properties of Populus clones. IAWA Journal, 15(3), 311-321.

[19] Rao, R.V. and Shashikala, S. (2003) Assessment of growth rate, basic density and heart wood content in selected teak clones of CSO, Thithimathi in Karnataka state, India. In International Conference on Quality Timber
Products of Teak from Sustainable Forest Management, 2-5 December 2003, KFRI, Kerala, India (abstracts), 57.

[20] Pande, P.K. and Singh, M. (2005) Intraclonal, inter-clonal and single tree variations of wood anatomical properties and specific gravity of clonal ramets of Dalbergia sissoo Roxb. Wood Science Technology, 39(5), 351-366.

[21] Veenin, T., Fujita, M., Nobuchi T. and Siripatanandilok, S. (2005) Radial variations of anatomical characters and specific gravity in Eucalyptus camaldulensis clones. IAWA Journal, 26, 353-361.

[22] Pande, P.K. (2005) Assessment of the performance of different clones of Dalbergia sissoo and Eucalyptus tereticornis on the basis of wood quality under different farm forestry programs. FTR submitted to ICFRE, Dehradun, India.

[23] Pande, P.K. and Singh, M. (2003) Variation in wood elements within a ramet of Dalbergia sissoo. Journal of Timber Development Association India, 2(3-4), 19-22.

[24] Mandal, A.K. and Chawaan, P.H. (2003) Investigations on inheritance of growth and wood properties and their inter-relationship in teak. In International Conference on Quality timber products of teak from sustainable forest management (abstracts), Kerala, India, 56.

[25] Tomazello, F. and Variacano, M. (1987) Radial da densidade basica e da estrutura anatomica da Madeira do Eucalyptus globulese, E. pellitae, E. acmenioides. Inst Pesq. Estud. Florest. Piracicaba, (36).

[26] Bhat, K.M., Bhat, K.V. and Dhamodaran, T.K. (1990) Wood density and fiber length of Eucalyptus grandis grown in Kerala, India. Wood Fiber Science, 22, 54-61.

[27] Okuyama, T., Yamamoto, H., Wahyudi, I., Hadi, Y.S. and Bhat, K.M. (2003) Some wood quality issues in planted teak. In International conference on quality timber products of teak from sustainable forest management, Kerala, India, 2-5 December 2003, 21. 